\title{
The Role of Relationship Learning and Institutional Environment in Business Model Innovation
}

\author{
Xiaoying Pan \\ School of Management, Wuhan University of Technology,Wuhan,P.R.China,430070 \\ a1045156632@foxmail.com
}

\begin{abstract}
Keywords: Entrepreneurial Social Capital; Relationship Learning; Institutional Environment; Business Model Innovation
\end{abstract}

\begin{abstract}
The business model innovation based on the Internet and information technology changes the method of value creation and the source of the competitive advantage of the company. Study has shown that entrepreneur political social capital has a positive impact on novel business model innovation. However, with the improvement of the institutional environment, the resources will be gradually optimally deployed, and will no longer be subject to political association of entrepreneurs too much, that is, the impact of the entrepreneur political social capital will be reduced. At the same time, the positive impact of entrepreneur commercial social capital on business model innovation is moderated by relationship learning.
\end{abstract}

\section{Introduction}

The promotion of business model innovation is closely related to practical issues such as China's economic transformation and the construction of an innovative country. Many companies have grown rapidly through business model innovation under highly resource-constrained and uncertain conditions, and some have even changed the pattern of industrial competition. However, some enterprises that have long been known for their resources and strategic analysis often fail.(Yun Lexin,2017) ${ }^{[1]}$

Innovation refers to the establishment of innovative systems, adopting new business models or attempting to establish new rules in existing business models, and conducting business concepts' innovation, and thinking about existing business concepts from a new perspective.(Hamel,Gary,2000) ${ }^{[13]}$ Any enterprise has its own business model. The core of the business model is to answer the two basic questions of "what value to create" and "how to create value". Business model innovation is the focus of China's enterprises to implement innovation-driven development strategies. It plays an important role for enterprises to gain market advantage in the context of a new competitive environment.

Since Timmers (Timmers $P, 1998)^{[2]}$ first proposed the concept of business model, the interpretation of the business model has always been divergent. The conceptual models of business models such as three-dimension(Zhang Jingwei,2010) ${ }^{[3]}$, four-facet(Hamel,Gary,2000) ${ }^{[13]}$, nine-element(Osterwalder A,2010 ${ }^{[4]}$, and transaction mix model(Amit,2012) ${ }^{[5]}$ all have a great impact. Scholars base their research on the value chain theory, technology innovation theory, resource theory and other perspectives, using case studies, literature induction, and deduction methods, and form their own viewpoints from different perspectives of operations, profitability, strategic positioning, system theory, etc.(Cheng Wen,2014) ${ }^{[12]}$

The business model based on operations focuses on value creation, value transfer activities and corresponding support systems of enterprises, examines the value activities of enterprises in the social value network, and emphasizes the way enterprises are embedded in the business ecosystem. The operating model refers to the business process, organizational design, and management of other participants' relationships in the process of creating and delivering value. Although focusing on the logic of value creation, the business model focused on operations neglects the question of where the economic returns come from, that is, the value acquisition. Nor does it mention the question of who the company serves and for whom. Companies need to find a unique and advantageous positioning and design their operational activities. The essence of positioning is embodied in the value 
proposition of the enterprise, ie, what kind of value is provided to which customers by what kinds of products and services. (Cheng Wen,2014) ${ }^{[12]}$

The earliest business model based on system theory includes two aspects: business model and profit model. (Timmers P,1998) ${ }^{[2]}$ The business model must not only satisfy the company's current revenue and profit demands, but also serve the future development. (Itami H,2009) ${ }^{[6]}$ The profit model not only makes sense for the company's current earnings, but also conveys the strategic intention of the company to create competition differences. The realization of strategic intentions benefits from the company's operating system.

Most of the existing literature attribute the definition of business model to multi-angle integration. Amit and Zott also further deconstructed the business model into content, structure, and governance in 2012.(Amit,2012) ${ }^{[5]}$ The content dimension focuses on the value attributes and related activity attributes created by the business model; The structural dimension emphasizes the trading partners' attributes and interactive arrangements in the value creation network. The governance dimension focuses on the distribution of benefits, incentives and constraints among trading partners. Corresponding to this, business model innovation is characterized by the presence of factors and characteristics that differ from those in the industry in these three dimensions. (Yun Lexin, 2017) ${ }^{[1]}$ Embodies the value creation, value-added activities, the introduction of new trading partners and trading mechanisms.

Business model innovation as a new organizational approach, (Casadesus, 2013) ${ }^{[7]}$ theoretical analysis perspective is also varied, such as resource-based theory, resource dependence theory, transaction cost theory, value chain theory.(Guo Hai,2014) ${ }^{[8]}$ Enterprises can integrate and configure resource development opportunities through creativity; minimize reliance on the environment and other organizations by means of mergers and lobbying; innovate trading channels; and optimize and innovate enterprise value activities on the value chain to acquire key resources needed for business model innovation, promote the establishment of competitive advantages, and create value. There are also researchers who divide business model innovations into novelty and efficiency.(Li Wei,2017) ${ }^{[9]}$

Based on the above discussion, it can be seen that the business model, as the infrastructure for the operation of an enterprise, is the internal logic for the enterprise to obtain and maintain its competitive advantage, and is an expression of its strategic positioning, operational characteristics, and revenue model. Value is the core concept of defining the business model.(Zott C,2011) ${ }^{[10]}$ Based on value propositions, companies construct value-creation networks, realize value transmission and acquisition, and satisfy business stakeholders' value propositions while improving business performance, and continue to improve, that is, through business model innovation, value claim recycling, value network construction, value communication innovation can be of great benefit in responding to changing challenges in the external environment. This point has also been reflected in the research of Luo Shuxin and Wang Xiangxiang.(Luo Shuxin,2016) ${ }^{[11]}$

\section{Conceptual Model}

Fig. 1 depicts the model of this article. Although entrepreneurial business social capital and political social capital support the business model innovation to some extent, This paper believes that the impact of two types of entrepreneurial social capital on business model innovation is moderated by different factors. Relationship learning will enhance the positive impact of entrepreneurial business social capital on business model innovation, and the influence of entrepreneurial political social capital on business model innovation will be moderated by the institutional environment.

The theory of business model describes and analyzes the existence of a company. It is an important tool for achieving management innovation and provides a technical route for the creation and innovation of a company.(Cheng Wen,2014) ${ }^{[12]}$ Companies need to develop a strategy that distinguishes them from their competitors, build different business models to meet the needs of the new economic era, and create a sustainable competitive advantage for the company.(Hamel,Gary,2000) ${ }^{[13]}$ The enterprise's competitive advantage is closely related to the value ecosystem in which it is located. Especially in the context of the current Internet era, the 
development of information network technology has promoted the formation of innovation networks, and the value network of enterprises will directly determine the survival and development of enterprises.

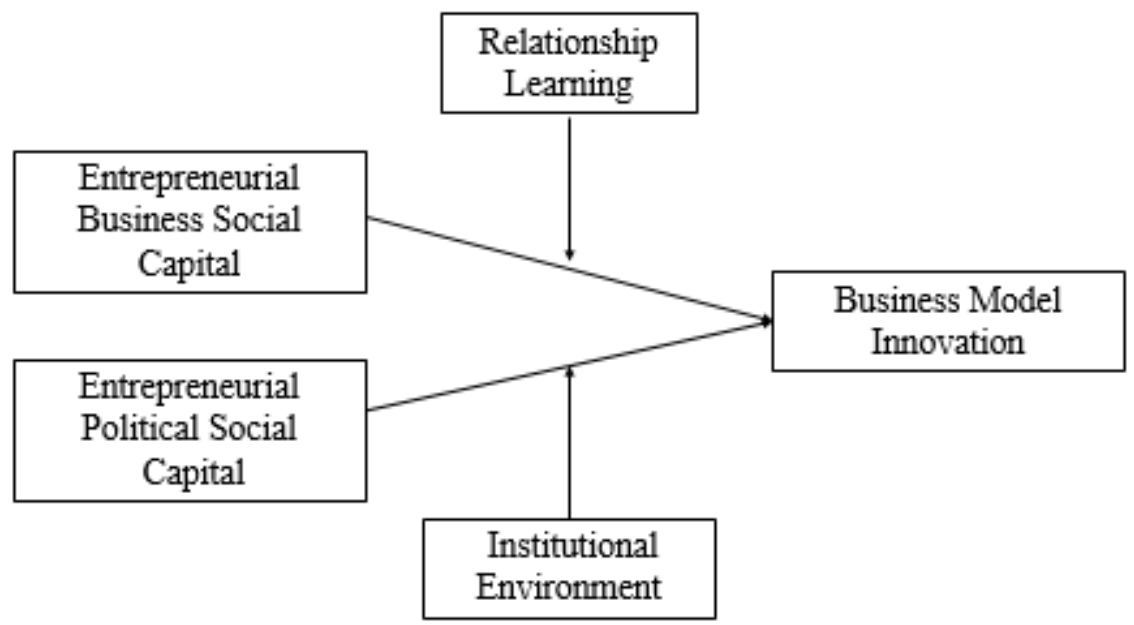

Figure 1. the Role of Relationship Learning and Institutional Environment in Business Model Innovation

First of all, network embeddedness, that is, the stronger the relationship or dependence between an enterprise and various types of networks, (Halinen A,2013) ${ }^{[14]}$ the more likely high-quality information can be quickly disseminated(Li Feixing, Hu Zhenhua,2016) ${ }^{[15]}$ and can provide critical information for enterprises. Social capital is an important intangible asset for enterprises to search for information, obtain opportunities, and connect external resources. As a specific resource, Only if it affects the behavior of the company it can be effective. Yun Lexin et al. (Yun Lexin,2017) ${ }^{[1]}$ also pointed out that the embedded network structure of start-up companies will promote business model innovation by promoting acquired learning. It can be seen that the embedded network structure of the enterprise provides a favorable connection for business model innovation. Entrepreneurial social capital, as a collection of social relationships owned by entrepreneurs and possessing resource extraction functions, is an important resource for enterprises to obtain competitive advantages in today's turbulent market environment. Based on the distinction between entrepreneurial business social capital and political social capital, Li Wei (Li Wei,2018) ${ }^{[16]}$ pointed out that the social network established between entrepreneurs and business partners, namely entrepreneurial business social capital, will have a positive effect on the novel and efficient business model innovation of manufacturing enterprises.

At the same time, due to the increasing dependence of corporate innovation on external resources and the increasing interaction between innovative entities, the relationship learning ability has become an important factor in the success of corporate innovation.(Wang Liping,2016) ${ }^{[17]}$ The stronger the ability to learn and communicate with the upstream and downstream companies to form external behaviors through communication, adjustment, and cooperation, the more significant the role of entrepreneurial business social capital in promoting business model innovation. Therefore:

H1: Relationship learning positively moderates the relationship between entrepreneurial business social capital and business model innovation.

The entrepreneur political social capital does not always promote the innovation of business models. (Li Wei,2018) ${ }^{[16]}$ The social network relationships among entrepreneurs and officials at all levels and officials of various supervisory and administrative agencies at all levels are conducive to the company's acquisition of key development resources, the promotion of new business models, the formation of business networks, and the promotion of innovative business model innovations, but it do not significantly affect existing trades within the industry. This article believes that this is caused by the institutional environment. The process of improving the institutional environment is gradual. The more developed the institutional environment is, namely, the more perfect the market 
mechanism, the higher level of government governance and the rule of law, the better the protection of property rights and investment income of enterprises, the smaller the transaction costs and risks, and the more conducive to the improvement of the trading mechanism. The positive effect of model innovation is stronger. Moreover, a good institutional environment is very favorable for the optimal allocation of resources.(Yang Xiaoyou,2005) [18]With the improvement of the institutional environment, the influence of entrepreneur political social capital on the acquisition of key resources by enterprises will be reduced. Therefore:

H2: The institutional environment moderates the relationship between entrepreneurial political social capital and business model innovation. The more perfect the institutional environment, the weaker the relationship between entrepreneurial political social capital and the innovation of business models, and vice versa.

\section{Conclusions}

At present, enterprises with strong technical strength are also very difficult to have all the resources needed for innovation. With the gradual improvement of the institutional environment, the allocation of resources will be more rationalized and transparent, the efficiency of resource allocation will be higher, and it will be conducive to the resources' exchange between enterprises and the outside world. At the same time, the influence of entrepreneurial political social capital on the ability of obtaining policy support and improve transaction efficiency will be reduced.

Learning and interaction between innovative subjects are key to business model innovation. It is true that the business model emphasizes the construction of activity systems and the integration of external partners with the core of value creation logic. Strengthening relationship learning can help companies enhance their value creation capabilities. Constantly interacting with the external environment, enhancing communication with other innovative entities, grasping development opportunities, and effectively grasping the incremental space for resources brought by network connectivity will help companies optimize value creation networks, improve revenue models, effectively communicate value propositions and fulfill business model innovation.

\section{References}

[1] L.X. Yun, J. Yang and Y.L. Zhang. How do startup companies achieve business model content innovation?--- Cross-case study based on the dual mechanism of "network-learning" [J].Management World, 2017(4):119-137. (In Chinese)

[2] Timmers P. Business Models for Electronic Markets[J]. Electronic Markets, 1998, 8(2):3-8.

[3] J.W. Zhang and Y.J. Wang. Research on Conceptual Model of Business Model Based on Value Triangle Logic[J]. Foreign Economy and Management,2010(6):1-8. (In Chinese)

[4] Osterwalder A. The Business Model Ontology - A Proposition in a Design Science Approach[J]. Ecole Des Hautes Etudes Commerciales Universite De, 2010.

[5] Amit, Raphael; Zott, Christoph. Creating Value Through Business Model Innovation [J]. MIT Sloan Management Review,2012,53(3):41-49

[6] Itami H, Nishino K. Killing Two Birds with One Stone : Profit for Now and Learning for the Future[J]. Long Range Planning, 2009, 43(2):364-369.

[7] Casadesus - Masanell R, Zhu F. Business model innovation and competitive imitation: The case of sponsor - based business models[J]. Strategic Management Journal, 2013, 34(4):464-482.

[8] H. Guo and R. Shen. How to translate entrepreneurial opportunities into corporate performance - the mediating role of business model innovation and the regulatory role of market environment[J]. Economic Theory and Business Management,2014, V34(3):70-83. (In Chinese)

[9] W. Li, C. Ding. Research on the Mechanism of Market Model Efficiency Driven by Business Model Innovation — The Moderating Effect of Marketing Dynamic Capabilities[J]. Business Economics and Administration,2017, 1(4):70-79. (In Chinese) 
[10] Zott C, Amit R, Massa L. The Business Model: Recent Developments and Future Research[J]. Social Science Electronic Publishing, 2011, 37(4):1019-1042.

[11] S.X. Luo and X.X. Wang. The path of innovation in the business model of small and micro enterprises based on value creation[J]. Management World,2016(8):184-185. (In Chinese)

[12] W. Cheng, Y.J. Wang, J.Y. Gao, et al. Review of the Evolution of Business Model Theory[J].Management Journal,2014, 11(3):462. (In Chinese)

[13] Hamel, Gary. Leading the revolution[M]. Boston, 2000.

[14] Halinen A, Törnroos J A, Elo M. Network process analysis: An event-based approach to study business network dynamics[J]. Industrial Marketing Management, 2013, 42(8):1213-1222.

[15] F.X. Li and Z.H. Hu. The influence of global network embedding, local network embedding and competitiveness of internationalized agricultural enterprises[J]. Economic Geography,2016, 36(7):122-131. (In Chinese)

[16] W.Li, Z.H. Dai and C.Ding. A Study on the Mechanism of Entrepreneur Social Capital Affecting Operational Performance_—A Perspective of Business Model Innovation[J]. East China Economic Management,2018(2):51-57. (In Chinese)

[17] L.P. Wang and F.Y. Zhao. Organizations forgetting, Relationship Learning, Enterprise Openness, and Business Model Innovation [J]. Research Management,2016, V37(3):42-50. (In Chinese)

[18] X.Y. Yang. Regional Institutional Environment and Countermeasures for Regional Competition[M]. Central South University Press,2005. (In Chinese) 